\title{
PENDEKATAN SOSIAL BUDAYA DALAM PENYELESAIAN POTENSI KONFLIK PENDIRIAN RUMAH IBADAH: Pendirian Vihara dan Masjid di Banyumas
}

\section{Social Cultural Approach in Overcoming Conflict Potency in Building Worship Places: The Building Of Vihara And Mosque In Banyumas}

\author{
Mustolehudin \\ Balai Penelitian dan Pengembangan Agama Semarang \\ Jl. Untung Suropati Kav. 69-70 Bambankerep, Ngaliyan, Semarang \\ Email: tole_dilla@yahoo.co.id
}

Naskah diterima tanggal 12 Januari 2015. Naskah direvisi tanggal 10 Februari 2015. Naskah disetujui tanggal 22 Mei 2015

\begin{abstract}
Abstrak
Fokus penelitian ini adalah membahas persoalan mengapa masyarakat menolak atau menerima pendirian sebuah rumah ibadah dengan alasan administrasi, teologis, dan sosiologis. Dengan menggunakan metode deskriptif analisis terhadap data-data kualitatif, yang dikumpulkan melalui FGD, wawancara, observasi, dan telaah dokumen, dalam penelitian ini diperoleh temuan sebagai berikut: Pertama, bahwa pendirian rumah ibadah di Banyumas bukan saja bermuara pada persoalan perijinan secara administratif, melainkan karena adanya faktor ideologis dan sosiologis. Kedua, bahwa alih fungsi ruko menjadi Vihara Prajna Maitreya yang semula mendapat penolakan dari warga sekitar Kelurahan Sokanegara dapat diselesaikan dengan pendekatan sosial budaya yang dilakukan oleh FKUB Kabupaten Banyumas, Kementerian Agama Kabupaten Banyumas, tokoh lintas agama, tokoh masyarakat, tokoh budaya, dan pemerintah daerah. Ketiga, bahwa regulasi PBM No 8 dan 9 tahun 2006, dalam praktik di daerah belum optimal dalam pelaksanaannya. Hal ini dapat diketahui bahwa, mayoritas rumah ibadah terutama masjid belum menerapkan PBM tersebut.
\end{abstract}

Kata kunci: rumah ibadah, vihara, masjid, ideologis, sosiologis

\begin{abstract}
This research focuses on the reasons why people accept or reject in building place of worship, whether it might be related to administrative aspects, theology or sociological reasons. This study employed descriptive analysis in order to examine the qualitative data. Meanwhile, the data were collected by using four specific methods namely Focus Group Discussion, interviews, and observation as well as document analysis. The findings show that the problems of building place of worship were influenced by theology, sociology and administrative factor. The problem related to the changing function of a shop to be a Vihara Prajna Maitreya that was initially rejected by community can be solved with social and cultural approach by FKUB, Ministry of Religious Affairs, inter-religious leaders, community leaders, cultural leaders and local government in Banyumas District. The PBM regulations no 8 and 92006 have not been implemented fully. This can be seen from the fact that most of the house of worship especially mosques have not applied the PBM.
\end{abstract}

Keywords : worship, vihara, mosque, theology, and sociology.

\section{PENDAHULUAN}

$\mathrm{P}$ ersoalan pendirian rumah ibadah atau alih fungsi pemanfaatan bangunan gedung bukan rumah ibadah di suatu daerah acapkali dapat berujung pada konflik horisontal. Laporan tahunan kehidupan beragama di Indonesia tahun 2011 yang dilakukan CRCS UGM Yogyakarta menjadi bukti nyata bahwa pendirian rumah ibadah berpotensi menimbulkan konflik. Berikut ini adalah contoh- 
contoh kasus pengrusakan, penyegelan, dan penutupan rumah ibadah di Indonesia, sebagai berikut: 1) Kasus pembekuan aktifitas dan penutupan masjid Jemaat Ahmadiyah di Samarinda, 2) penyerangan sekelompok massa terhadap Gereja Katolik Petrus dan Paulus di Temanggung, 3) penyerangan sekelompok massa terhadap Gereja Pantekosta di Kaloran, penyerangan Gereja GPIB Bekasi, 4) penutupan dan pengalihfungsian masjid Ahmadiyah di Depok, 5) penyegelan GKI Taman Yasmin Bogor, 6) penyegelan masjid Ahamdiyah di Karanganyar Jawa Tengah, 7) teror bom di halaman Gereja Pantekosta Pasar Surabaya, 8) pembakaran Kapela Katolik Santo Antonius di Air Molek Riau, 9) pembongkaran masjid Raudatul Islam oleh pihak pengembang di Medan, dan ledakan bom bunuh diri di masjid Polres Cirebon (Bagir, et.all, 2011: 48 $-49)$.

Berkaca dari berbagai peristiwa konflik di Nusantara tersebut, para tokoh agama, tokoh masyarakat, tokoh budaya di Banyumas pada sekitar akhir 1997 dan awal 1998 berinisiatif mendirikan Forum Komunikasi Antar Umat Beragama (FKAUB), sebelum secara resmi pemerintah mendirikan Forum Kerukunan Umat Beragama pada tahun 2006 (Roqib, 2012: 44). Melalui forum inilah, berbagai potensi konflik yang muncul di Banyumas dapat diredam dengan pendekatan sosial budaya.

Salah satu budaya yang cukup unik di Banyumas adalah budaya cablaka (berkata apa adanya) dan unen-unen ana rembug dirembug (apabila ada persoalan diselesaikan dengan dialog). Interpretasi yang dilakukan (Priyadi, 2008: 159) terhadap budaya Banyumasan menjelaskan bahwa budaya cablaka adalah menyampaikan sesuatu tanpa tedeng aling-aling yang berarti menyampaikan dengan apa adanya. Budaya cablaka telah menjadi karakter masyarakat Banyumas. Lebih lanjut dijelaskan bahwa "cablaka", telah menempatkan dirinya sebagai hasil sintesis antara tesis dengan antitesis sehingga terdapat keseimbangan nilai. Nilai cablaka menjadi titik pusat sistem yang berinteraksi dengan komponen-komponen lainnya.

Penelitian tentang pendirian rumah ibadah telah dilakukan oleh berbagai pihak. Namun demikian, aspek yang diteliti baru sebatas pada aspek administrasi dan belum menyentuh pada aspek mendasar yang terjadi dalam masyarakat. Ibnu Hasan Muchtar (2010 : 98) dalam penelitiannya menyebutkan bahwa, di Kota Bekasi sebagian besar tempat ibadah belum menaati PBM tersebut. Sementara itu, Ahsanul Khalikin (2010: 190) menjelaskan bahwa di Kota Depok, PBM No 9 dan 82006 tersebut ditengarai adanya diskriminatif oleh suatu kelompok tertentu. Senada dengan hasil penelitain tersebut di atas, penelitian yang dilakukan Puslitbang Kehidupan Keagamaan Badan Litbang dan Diklat tahun 2012, hasil penelitian menunjukkan bahwa sebagian besar wilayah di Indonesia pelaksanaan PBM sudah dilaksanakan meskipun belum maksimal.

Berpijak dari latar belakang tersebut, penelitian tentang pendirian rumah ibadah dengan pendekatan sosial budaya di Kabupaten Banyumas menjadi penting dilakukan. Fokus yang dikaji dari penelitian ini adalah mengapa masyarakat menolak atau menerima pendirian rumah ibadah baik secara administrasi, teologis, dan sosiologis.

\section{METODE PENELITIAN}

Penelitian ini adalah termasuk dalam kategori penelitian kualitatif, yakni penelitian yang ditujukan untuk menghasilkan data berupa kata-kata tertulis atau lisan dari orang-orang-orang yang diamati (Moleong, 2000: 4). Jenis penelitian ini adalah penelitian kasus yaitu penelitian yang bertujuan untuk mempelajari secara intensif mengenai unit sosial tertentu meliputi individu, kelompok, atau lembaga (Zuriah, 2006: 48). Pengumpulan data dalam penelitian ini dilakukan dengan teknik Focus Group Discussion (FGD), wawancara, observasi dan studi dokumen. Informan kunci dalam penelitian ini adalah tokoh lintas agama, tokoh budaya, tokoh masyarakat, dan tokoh lembaga (Kementerian Agama Kabupaten Banyumas dan FKUB Kabupaten Banyumas).

Analisis yang digunakan dalam penelitian ini adalah analisis deskriptif. Tujuan analisis ini untuk membuat suatu gambaran atau lukisan secara sistematis, faktual dan akurat, mengenai fakta-fakta, sifat-sifat serta hubungan antara fenomena yang diselidiki. Data-data yang diperoleh kemudian dipaparkan dan dianalisis dengan teknik deskriptif, yang merupakan suatu alur kegiatan yang meliputi: reduksi data, penyajian data, dan menarik kesimpulan. Analisis penelitian ini tidak hanya dijelaskan dengan kalimat-kalimat yang dideskripsikan, tetapi sedapat mungkin memberi kejelasan obyek penelitian yang dilakukan (Moleong, 2000: 36) 


\section{PEMBAHASAN}

\section{Setting sosial budaya keagamaan di Banyumas}

Wilayah Kabupaten Banyumas termasuk dalam kategori wilayah pedalaman di Jawa. Salah satu ciri utama wilayah ini adalah mempunyai keunikan dalam hal penggunaan bahasa. Masyarakat secara khusus menggunakan dialek Banyumasan atau dapat pula disebut bahasa penginyongan. Komunitas Banyumasan adalah mereka yang menggunakan bahasa ngapak-ngapak dalam kesehariannya (Suwito, 2008: 58).

Secara administratif, wilayah Kabupaten Banyumas terdiri dari 27 kecamatan. Wilayah ini berbatasan dengan daerah-daerah di sekitarnya. Batas-batas wilayah kabupaten ini adalah: di sebelah utara berbatasan dengan Kabupaten Tegal dan Kabupaten Pemalang, sebelah timur berbatasan dengan Kabupaten Purbalingga, Banjarnegara, dan Kebumen, sebelah selatan berbatasan dengan Kabupaten Cilacap, dan di sebelah barat berbatasan dengan Kabupaten Cilacap dan Brebes. Daerahdaerah yang tersebut di atas, dalam hal sosial budaya terdapat beberapa kemiripan terutama dalam hal pemakaian bahasa.

Secara geografis, luas wilayah Kabupaten Banyumas adalah 132.758 Ha sekitar 4,08\% dari luas wilayah Propinsi Jawa Tengah yaitu 3.254 Ha. Wilayah ini $32.292 \mathrm{Ha}$ merupakan areal persawahan dan merupakan salah satu kabupaten yang menjadi swasembada beras di Jawa Tengah. Selain areal persawahan, di wilayah ini juga terdapat areal perkebunan yang terletak di dataran tinggi gunung Slamet di Baturaden. Secara keseluruhan luas areal tegalan dan lain-lainnya adalah 51,798 ha (BPS Kabupaten Banyumas, 2013). Dengan luas yang cukup tersebut, wilayah ini juga menjadi sentra penghasil berbagai jenis sayuran, terutama Banyumas di wilayah pegunungan.

Potensi tersebut, di satu sisi merupakan kekayaan sumber daya alam yang tak ternilai yang menjadi sumber penghidupan bagi masyarakat Banyumas. Kemudian di sisi lain dengan tingkat penghasilan ekonomi cukup mapan yang bersumber dari hasil panen padi dan palawija di dataran pegunungan Slamet, akan mempengaruhi pola kehidapan masyarakat dalam kehidupan ekonomi, sosial, politik, seni, budaya dan keagamaan.

Penduduk Kabuapten Banyumas mayoritas adalah beragama Islam yaitu berjumlah 1.700.922 jiwa. Sementara itu, penduduk yang memeluk
Kristen berjumlah 17.979, pemeluk agama Katolik berjumlah 11.131 jiwa, pemeluk agama Hindu 1.136 jiwa, pemeluk agama Budha berjumlah 1.872, pemeluk agama Khonghucu berjumlah 239 jiwa, dan penduduk yang meyakini aliran kepercayaan berjumlah 445 jiwa (Kementerian Agama Kab. Banyumas, 2013).

Berkenaan dengan rumah ibadah di Kabupaten Banyumas, terdapat 8.712 rumah ibadah yang tersebar di 27 kecamatan. Berikut ini uraian jumlah rumah ibadah di Kabupaten Banyumas : masjid 1.995 buah, langgar 5.875 buah, mushalla 722 buah, Gereja Kristen 84 buah, Gereja Katolik 3 buah, kapel 11 buah, pure 1 buah, vihara 18 buah, dan klenteng 3 buah (Kementerian Agama Kab. Banyumas, 2013).

Potensi penduduk yang memeluk berbagai macam agama dan potensi jumlah tempat ibadah di atas, di satu sisi adalah merupakan sebuah modal untuk membangun kerukunan. Namun demikian di sisi lain, keragamaan pemeluk agama yang berbeda-beda dan pendirian rumah ibadah yang tidak mentaati peraturan pemerintah dalam hal pendiriannya dapat menjadi sumber konflik yang mengancam kerukunan dalam kehidupan umat beragama.

\section{Pendirian Vihara Prajna Maitreya}

Vihara Prajna Maitreya merupakan salah satu rumah ibadah umat Buddha di Purwokerto. Vihara ini tepatnya berada di jalan Ahmad Yani No. 18 Purwokerto. Vihara Prajna Maitreya secara administrasi berada di Kelurahan Sokanegara, Kecamatan Purwokerto Timur, Kabupaten Banyumas. Vihara ini sebelumnya merupakan sebuah ruko yang kemudian beralih fungsi menjadi tempat ibadah. Awal beralih fungsinya tempat ibadah ini, penduduk di sekitar ruko tersebut menolak dengan keberadaan Vihara ini. Penolakan warga di sekitar ruko tersebut, berawal dari adanya surat rekomendasi dari Kelurahan Sokanegara No. 551.2/081/III/2011 tanggal 9 Maret 2011 yang berisi tentang tindak lanjut permohonan ijin sementara pemanfaatan bangunan gedung untuk Vihara Prajna Maitreya.

Berkenaan dengan munculnya potensi konflik tersebut, FKUB Kabupaten Banyumas melakukan upaya pendampingan untuk menyelesaikan potensi konflik Vihara Prajna Maitreya. Selanjutnya ketua FKUB Kabupaten Banyumas membentuk tim 
pendampingan agar kasus beralih fungsinya ruko tidak berlarut-larut dan menimbulkan konflik bagi warga di sekitar Kelurahan Sokanegara. Hal ini dikuatkan dengan dikeluarkannya surat keputusan ketua FKUB Kabupaten Banyumas Nomor: 56/ FKUB-BMS/XII/2011. Dasar hukum yang menjadi landasan dikeluarkannya SK ini adalah merujuk pada Peraturan Bersama Menteri Agama dan Menteri Dalam Negeri No. 9 dan 8 Tahun 2006 Bab IV pasal 13, 14, 15, 16, dan 17 tentang pendirian rumah ibadah.

Jika dilihat dari komposisi jumlah penduduk yang beragama Budha di Kelurahan Sokanegara, umat Budha di kelurahan ini berjumlah 34 jiwa. Dari jumlah tersebut secara administrasi tentu tidak memenuhi syarat untuk mendirikan sebuah rumah ibadah. Akan tetapi, jika merunut pada Peraturan Bersama Menteri Agama dan Menteri Dalam Negeri No. 9 dan 8 Tahun 2006 bab IV pasal 13 ayat 3 dijelaskan. Jika di suatu wilayah akan mendirikan tempat ibadah harus memenuhi persyaratan dengan mendapatkan persetujuan dari 90 warga pengguna dan 60 tanda tangan dukungan persetujuan dari lingkungan sekitar. Apabila jumlah tersebut belum terpenuhi, panitia dapat meminta persetujuan dari wilayah lain, mulai dari tingkat desa atau kelurahan, kecamatan, kabupaten/kota, sampai dengan provinsi.

Dengan adanya peraturan tersebut, akhirnya panitia melakukan upaya untuk memenuhi semua persyaratan pendirian rumah ibadah. Hal ini dibuktikan dengan ijin tertulis dari pemilik bangunan atas nama Tan Jok Lan yang akan difungsikan sebagai Vihara yaitu sebuah Ruko Nomor 3 yang terletak di Jl Ahmad Yani No. 8 Rt 03 Rw 06 Kelurahan Sokanegara Kecamatan Purwokerto Timur Kabupaten Banyumas. Selain itu juga dikuatkan dengan adanya surat pernyataan dari bapak Edy Susanto pemilik Ruko No 2 yang berada di sebelah utara, kemudian bapak Edhi Lutojo pemilik Ruko No 4 yang berada di sebelah selatan yang menyatakan bahwa tidak keberatan atas beralih fungsinya Ruko No 3 menjadi tempat ibadah umat Buddha berupa Vihara.

Kemudian setelah segala persyaratan dipenuhi dan dilakukan verifikasi data, survey, dan rapat beberapa kali dengan beberapa pihak terkait, FKUB Kabupaten Banyumas menyampaikan "pendapat tertulis kepada Bupati Kabupaten Banyumas. Selanjutnya berdasarkan hasil yang telah dilakukan
FKUB Kabupaten Banyumas, diputuskan bahwa permohonan pemanfaatan ruko untuk tempat ibadah sudah sesuai dengan PBM, dengan catatan pihak pengelola Vihara tetap menjaga kerukunan, keamanan, perparkiran, dan memperhatikan kondisi bangunan. Selain itu pula, panitia agar mengurus berbagai keperluan perijinan kepada Bupati sendiri setelah pendapat tertulis FKUB disampaikan. Di samping itu, pihak pengelola Vihara agar secara berkala mengkomunikasikan kondisi terkini Vihara jika terjadi hal-hal yang mengancam kerukunan dan keamanan (FKUB Kab Banyumas, 2011).

\section{Pendirian Masjid Baiturrahman}

Masjid Baiturrahman merupakan salah satu masjid yang dalam pendiriannya menyesuaikan dengan PBM No 9 dan 8 tahun 2006, terutama yang berkaitan dengan pasal pendirian rumah ibadah. Saat penelitian ini berlangsung, masjid ini sedang proses pengurusan ijin pendirian rumah ibadah. Secara administrasi, pendirian masjid Baiturrahman sudah mendapatkan rekomendasi dari Kementerian Agama Kabupaten Banyumas dengan Nomor: Kd.11.02/6/BA.04/1451/2014. Namun demikian, berdasarkan hasil FGD yang dilakukan FKUB Kabupaten Banyumas dan Kementerain Agama Kabupaten Banyumas, rekomendasi dari FKUB belum ada (FGD, Banyumas 10-9-2014).

Masjid yang sedang dalam proses pembangunan ini, terletak di jl. Ragasemangsang wilayah RT. 01 RW. 005 Kelurahan Sokanegara Kecamatan Purwokerto Timur, Kabupaten Banyumas. Secara administrasi, pendirian masjid Baiturrahman sudah mendapat dukungan dari lingkungan sekitar berupa 60 tanda tangan dan foto copy KTP. Selain itu pula, sebagaimana disebutkan dalam pasal 14 poin (a) pendirian masjid sudah mendapat dukungan pengguna yang dibuktikan dengan 90 tanda tangan dan foto copy KTP.

Secara geografis, masjid yang berada di jalan Ragasemangsang ini berada di sekitar alun-alun Purwokerto, tepatnya berada di pojok utara sebelah timur alun-alun. Di Kelurahan Sokanegara yang terdiri dari 12 RW terdapat 11 masjid yang tersebar di beberapa RT. Masjid-masjid tersebut adalah 1) masjid At-Taqwa berada di wilayah RT. 03 RW. 001, masjid Agung Baitussalam berada di alun-alun Purwokerto sebelah barat tepatnya di wilayah RT. 001 RW. 002, masjid Baabussalam di RT. 002 RW. 
006, masjid Baiturrohmah di RT. 04 RW. 006, masjid Al Fatah di RT. 001 RW. 007, masjid Sukadana di RT. 02 RW. 007, masjid Baiturrohmah di RT. 02 RW. 008, masjid Nurul Hikmah di RT. 04 RW. 008, masjid Al Ikhsan di RT. 03 RW. 009, masjid Besar Jendral Soedirman di RT. 03 RW. 011, dan masjid 17 (tujuh belas) berada di wilayah RT. 02 RW. 12. Sedangkan untuk di RW 005 belum terdapat masjid, dan di RW inilah masjid Baiturrahman proses pembangunan sedang berlangsung.

Seperti proses beralih fungsinya vihara Prajna Maitreya, masjid Baiturrahman ini juga melalui proses yang panjang dalam pendiriannya. Proses yang dilakukan adalah panitia melakukan sosialisasi kepada warga yang dihadiri beberapa tokoh agama dan warga sekitar yang dilakukan pada hari Minggu, 15 Desember 2013. Selain sosialisasi kepada warga yang beragama Islam, panitia juga melakukan sosialisasi kepada warga non muslim dan mereka mendukung yang dibuktikan dengan tanda tangan dan foto copy KTP.

Selain sosialisasi kepada warga lingkungan sekitar masjid, panitia juga melampirkan surat persetujuan dari tetangga di sekitar masjid Baiturrahman. Berdasarkan Perda No. 7 tahun 2011 pasal 9 ayat 9 huruf (a) tentang izin mendirikan bangunan. Masjid ini sebelah selatan bagian kiri berdampingan dengan rumah Sri Sukaningsih, kemudian sebelah timur belakang berdekatan dengan rumah Mukti Ningsih, bagian depan adalah jalan raya, dan bagian kanan adalah gedung pemerintah.

Jika dilihat dari jumlah dukungan terhadap pembangunan masjid Baiturrahman dapat diketahui bahwa dukungan dari penduduk yang beragama Islam mendapat dukungan paling banyak yaitu $70 \%$, sedang sisanya $25 \%$ dukungan dari pemeluk agama Katolik, dan 5\% adalah dukungan dari pemeluk agama Kristen. Bukti tanda tangan tersebut baik dari pendukung maupun pengguna telah diketahui oleh ketua RT. 02 RW. 5, ketua RW. 5, dan disahkan oleh Lurah Sokanegara.

\section{Penolakan \\ Aspek administratif}

Sebagaimana telah disinggung di awal, beralih fungsinya bangunan ruko yang kemudian berubah menjadi vihara, berpotensi menimbulkan konflik bagi lingkungan di sekitar vihara. Hal ini dapat diketahui dari hasil musyawarah tim pendampingan vihara Prajna Maitreya yang dilakukan pada 29 November 2011. Salah satu hasil rapat tersebut adalah bahwa masyarakat sekitar ruko pada awalnya menolak dengan keras rencana alih fungsi dari ruko menjadi rumah ibadah.

Dengan adanya permasalahan yang timbul dan berpotensi menimbulkan potensi konflik tersebut, pada rapat koordinasi yang dilakukan tim pendampingan potensi konflik pendirian vihara Prajna Maitreya, diperoleh hasil sebagai berikut: 1) SKB 2 Menteri untuk ijin pendirian vihara dapat diberlakukan ijin sementara yaitu 2 tahun, apabila akan dilaksanakan perpanjangan harus mengajukan lagi, karena tidak boleh ruko untuk rumah ibadah, 2) panitia diharapkan agar melakukan koordinasi dengan Pemda terkait perda dan mekanisme ijin sementara, dan 3) masyarakat harus diberi sosialisasi ulang terkait rencana pendirian rumah ibadah.

Terkait dengan penolakan yang dilakukan oleh warga, akhirnya panitia pendirian vihara melengkapi persyaratan-persyaratan sesuai dengan PBM No 9 dan 8 Tahun 2006. Syarat-syarat yang dipenuhi untuk mendirikan rumah ibadah adalah ijin tertulis dari lingkungan sekitar, adanya dukungan yang dibuktikan dengan tanda tangan beserta foto copy KTP 90 pengguna tempat ibadah, adanya dukungan masyarakat setempat yang dibuktikan dengan tanda tangan dan foto copy KTP 60 warga, yang diketahui oleh kepala desa atau kelurahan. Selain itu juga adanya rekomendasi dari Kementerian Agama Kabupaten/Kota setempat dan rekomendasi dari FKUB Kabupaten Banyumas.

Kemudian sehubungan dengan adanya potensi konflik yang dapat timbul dari beralihfungsinya ruko menjadi vihara, FKUB Kabupaten Banyumas, Kementerian Agama Kabupaten Banyumas, dan Pemerintah Kabupaten Banyumas melakukan langkah-langkah antisipasi agar potensi konflik tersebut tidak menimbulkan kerugian bagi masyarakat dan panitia pendirian vihara. Forum yang digunakan adalah dengan melakukan diskusi intensif antara warga, panitia pendirian vihara, dan FKUB Kabupaten Banyumas.

Jika dilihat dari sejarah berdirinya FKUB di Kabupaten Banyumas, setidaknya dapat dianalisis bahwa proses beralih fungsinya ruko menjadi vihara meskipun sempat mendapat penolakan dari warga setempat, akan tetapi proses tersebut tetap berjalan baik karena adanya jalinan komunikasi yang baik yang dilakukan oleh FKUB Kabupaten Banyumas. 
Secara administratif, bahwa vihara ini awalnya sebuah ruko yang kemudian oleh pemilik ruko tersebut fungsinya berubah menjadi rumah ibadah.

Berbeda dengan alih fungsi ruko menjadi vihara, mengenai pendirian masjid Baiturrahman ini, sebagaimana dikemukakan dalam FGD yang disampaikan sekretaris FKUB Kabupaten Banyumas menyatakan bahwa sepanjang memenuhi persyaratan pemerintah dan sejauh menghormati lingkungan FKUB tidak akan mempersulit pembangunan masjid. Apabila ditelusuri secara administrasi, proses perijinan yang dilakukan panitia unsur-unsurnya belum terpenuhi secara menyeluruh. Seperti konfirmasi dari ketua FKUB Kabupaten Banyumas, bahwa dari Kementerian Agama kabupaten Banyumas sudah memberikan tembusan tentang pemberitahuan pembangunan masjid Baiturrahman. Namun demikian, surat yang secara khusus ditujukan kepada FKUB untuk menerbitkan rekomendasi pendirian masjid belum ada (FGD tanggal 10 September 2014).

Kasus pendirian vihara dan masjid di Purwokerto Timur, jika dianalisis dengan teori interaksi sosial, dapat diketahui bahwa interaksi sosial yang dijalin dengan baik antara tokoh masyarakat, tokoh agama, anggota masyarakat, dan FKUB Kabupaten Banyumas, dapat diredam melalui pendekatan budaya dan dialog. Potensi konflik dapat diselesaikan dan tidak menimbulkan gesekan secara fisik seperti yang terjadi di daerah lain. Komunikasi yang dilakukan beberapa tokoh agama di Banyumas merupakan sarana penting untuk membangun dan menciptakan kerukunan umat beragama baik intern maupun ekstern umat beragama.

FKUB Kabupaten Banyumas secara aktif telah melakukan pendampingan mengenai potensi konflik pendirian vihara Prajna Maitreya di Purwokerto. Diskusi yang dilakukan secara intensif dan berkelanjutan merupakan bukti nyata bahwa FKUB Kabupaten Banyumas telah melakukan interaksi dengan baik bersama masyarakat. Hal ini dapat diketahui dari pelaksanaan diskusi yang dilakukan pada tanggal 29 Januari 2011, rapat pengurus FKUB tanggal 24 Februari 2011, rapat pengurus FKUB dan ijin vihara tanggal 17 Maret 2011, rapat koordinasi pengurus tanggal 2 April 2011, rapat pada tanggal 21 Nopember 2011, rapat koordinasi pada tanggal 25 Nopember 2011, rapat koordinasi pada tanggal 29 Nopember 2011, rapat koordinasi pada tanggal 2 Desember 2011, dan rapat koordinasi pada tanggal 5 Desember 2011.
Jika dilihat dengan teori integrasi sosial, FKUB Kabupaten Banyumas telah melakukan integrasi dengan berbagai pihak sehingga potensi konflik yang muncul dapat diselesaikan melalui kerjasama sosial melalui pendekatan budaya dialog, sebagai berikut:

Gambar 1. Diagram teori integrasi sosial.

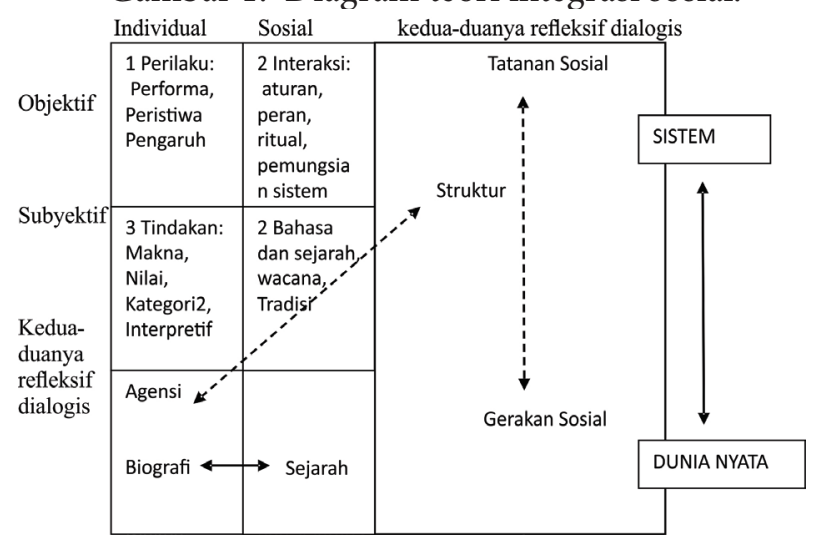

Sumber : (Habermas dalam Denzin dan Lincoln, 2009 : 462)

Berdasarkan teori integrasi sosial yang dikembangkan Habermas dalam (Denzin dan Lincoln, 2009: 464), tindakan komunikatif tampak menjadi sumber yang menjanjikan bagi pendekatan yang lebih komprehensif untuk persoalan-persoalan praktik sosial di masyarakat. Tindakan komunikatif yang dibangun FKUB Kabupaten Banyumas tidak terlepas dari peran pengaruh tokoh FKUB. Salah satu tokoh yang mempunyai pengaruh yang cukup besar dalam menciptakan kerukunan kehidupan beragama di Kabupaten Banyumas adalah KH. Dr. Moh Roqib, M.Ag, ketua FKUB Kabupaten Banyumas periode 2006-2010 dan periode 20102014. Meskipun bukan putra daerah KH. Dr. Moh Roqib, M.Ag, telah mampu menyelami budaya dan karakter masyarakat Banyumas. Sehingga setiap persoalan yang muncul dan berpotensi konflik dapat diselesaikan bersama tim FKUB yang di dukung oleh Pemerintah Daerah Kabupaten Banyumas maupun dukungan dari Kementerian Agama Kabupaten Banyumas.

Melalui teori ini, FKUB Kabupaten Banyumas telah bekerja secara dialogis dengan masyarakat dan pemerintah untuk bersama-sama menciptakan suatu kondisi masyarakat yang harmonis, aman dan rukun. Struktur masyarakat Banyumas yang mudah menerima perbedaan, di satu sisi merupakan modal budaya untuk mendapatkan suatu masyarakat yang ideal. Yaitu masyarakat yang berusaha untuk 
menghargai orang lain, menghormati kepercayaan agama lain, dan menghargai suatu perbedaan. Sehingga setiap potensi yang muncul di masyarakat, secara linier dapat ditemukan solusi pemecahannya. Seperti kasus alih fungsi ruko menjadi Vihara dan pendirian masjid Baiturrahman.

Perubahan sosial masyarakat Kelurahan Sokanegara yang merupakan wilayah kota di Purwokerto, memiliki keunikan dalam berbudaya. Keunikan budaya tersebut tercermin dalam perilaku nilai masyarakat yang tidak suka kepada konflik. Justru budaya cablaka masyarakat Banyumas menjadi pendorong untuk ikut membangun masyarakat menuju masyarakat yang aman, tentram, harmonis, dan sejahtera.

\section{Aspek Ontologi}

Beralih fungsinya rumah toko (ruko) nomor 3 yang berada di jalan A Yani No 18 Purwokerto menjadi vihara Prajna Maitreya, secara ontologi merupakan kebutuhan nyata bagi pemeluk agama Budha. Namun demikian, jika dilihat secara demografis penduduk Kelurahan Sokanegara yang memeluk agama Budha jumlah tidak mencapai 90 sebagaimana dijelaskan dalam pasal 14 poin b bahwa pendirian rumah ibadah paling sedikit mendapat dukungan 90 orang pengguna. Penduduk Kelurahan Sokanegara yang memeluk agama Budha berjumlah 34 orang menurut data dari Kementerian Agama. Akan tetapi jika dilihat secara luas dari kacamata Kabupaten Banyumas secara umum bahwa pendirian rumah ibadah apabila jumlah pengguna tidak mencukupi di suatu desa atau kelurahan, maka dapat meminta dukungan kepada tingkat di atasnya yaitu kecamatan dan seterusnya. Secara umum penduduk di Kabupaten Banyumas yang memeluk agama Budha berjumlah 1,872 jiwa atau sekitar $0,11 \%$. Sedangkan jumlah tempat ibadah agama Budha berupa vihara berjumlah 18 yang tersebar di berbagai daerah di Kabupaten Banyumas dimana wilayah kabupaten ini cukup luas.

Apabila didasarkan pada pasal 13 ayat 3 tentang pendirian rumah ibadah, dalam hal untuk keperluan nyata bagi pelayanan umat beragama di wilayah kelurahan/desa sebagaimana dimaksud pada ayat (1) tidak terpenuhi, pertimbagan komposisi jumlah penduduk digunakan batas wilayah kecamatan atau kabupaten/kota atau provinsi (Badan Litbang dan Diklat, 2008: 48). Wilayah Kelurahan Sokanegara berada di bawah Kecamatan Purwokerto Timur. Jika dilihat dari segi komposisi penduduk yang beragama
Budha, di Kecamatan Purwokerto Timur berjumlah 328 jiwa. Dengan demikian persyaratan dukungan 90 orang secara langsung mendapat dukungan dari wilayah kecamatan Purwokerto Timur.

Masyarakat Banyumas yang secara historis dibentuk oleh budaya Jawa pedalaman, berimplikasi terhadap keberagamaan masyarakatnya termasuk dalam hal kehidupan keagamaan. Masyarakat Banyumas seperti diungkapkan (Koentjaraningrat, 1985: 21) memiliki karakter yang unik. Keunikan tersebut dapat dilihat dari aspek bahasa (dialek Banyumasan), ritual siklus hidup, seni, budaya dan sosial. Terkait dengan pendirian rumah ibadah dalam hal ini beralih fungsinya ruko menjadi vihara masyarakat Banyumas cenderung dapat menerima meskipun pada awalnya menolak. Dalam pandangan filsafat materialisme, beralih fungsinya ruko menjadi vihara tidak menimbulkan konflik nyata bagi lingkungan sekitar. Namun, dalam realitasnya warga masyarakat sekitar ruko menolak keberadaan vihara tersebut. Akan tetapi pihak panitia setelah melakukan sosialisasi dan memenuhi persyaratan yang diatur dalam PBM No 9 dan 82006 tersebut mau menerima dengan catatan-catatan tertentu.

Dengan demikian dimungkinkan bahwa dengan adanya keberadaan vihara tersebut masyarakat merasa adanya ancaman dari pemeluk minoritas. Alih fungsi ruko menjadi vihara bagi masyarakat setempat dapat dimaknai sebagai bentuk persaingan antar umat beragama. Keberadaan vihara yang secara fisik merupakan bentuk nyata dari rumah ibadah umat Budha, jika dilihat secara ontologi termasuk dalam kategori ontologi materialisme. Namun, jika dilihat dari segi idealisme, terdapat realitas yang ingin dicapai oleh pemeluk umat Buddha lebih dari sekadar bentuk fisik vihara. Atas dasar realitas berdirinya sebuah vihara tersebut, masyarakat mempunyai pemikiran bahwa bentuk fisik vihara akan dapat mempengaruhi pola pikir untuk berubah keyakinan. Dengan demikian, masyarakat merasa khawatir akan terjadi perpindahan ideologi yang diawali dengan adanya bentuk bangunan vihara.

\section{Aspek Epistemologi}

Sehubungan dengan beralih fungsinya ruko menjadi tempat ibadah (vihara Prajna Maitreya), secara epistemologi dapat didekati dengan pendekatan fenomenologi. Edmund Husserl dalam (Praja, 2010: 179) menjelaskan bahwa untuk menemukan pemikiran yang benar, seseorang harus kembali kepada "benda-benda" itu sendiri. 
Secara realitas alih fungsi tersebut merupakan fenomena nyata yang terjadi di Kelurahan Sokanegara. Jika dilihat dari tempat ibadah umat Buddha di Kecamatan Purwokerto Timur sebelum berdiri vihara Prajna Maitreya, hanya terdapat satu vihara. Oleh karenanya berdirinya vihara ini secara epistemologi adalah sesuai dengan kebutuhan pemeluk agama Buddha tentang hak mendirikan rumah ibadah. Jika dihubungkan dengan jumlah umat Buddha di Kecamatan Purwokerto Timur yang berjumlah 328 jiwa, maka dengan satu vihara dirasa kurang mencukupi dan dimungkinkan kurang nyaman untuk beribadah.

Setidaknya terdapat tiga aspek penolakan warga terkait beralih fungsinya ruko menjadi vihara. Aspek tersebut adalah: 1) aspek teologis, 2) aspek sosiologis, dan 3) aspek ekonomi.

\section{Dimensi Teologis}

Berdirinya vihara Praja Maitreya yang semula adalah sebuah ruko dapat dilihat dari aspek teologis. Aspek teologis yang dimaksud di sini adalah bahwa masyarakat menolak dengan keras ruko menjadi vihara. Hal ini sebagaimana hasil rapat koordinasi tim pendamping potensi konflik pendirian vihara Prajna Maiteya umat Buddha pada tanggal 29 November 2011. Pada poin satu dan dua disebutkan bahwa masyarakat sekitar ruko pada awalnya menolak dengan keras rencana alih fungsi dari ruko menjadi rumah ibadah. Oleh karenanya, ketua RW di wilayah tersebut melayangkan protes kepada FKUB terkait rencana panitia pendirian rumah ibadah.

Setelah melalui beberapa pertemuan, dan pihak panitia melengkapi semua persyaratan yang ditentukan dalam PBM No. 9 dan 8 2006, warga menerima dengan catatan sebagaimana yang disepakati dapat rapat koordinasi tanggal 5 Desember 2011. Kesepakatan tersebut adalah: 1) pihak FKUB memberikan rekomendasi bahwa setelah mendasarkan pada peraturan tersebut, vihara tersebut layak diberi ijin sementara dengan catatan tidak merubah bentuk bangunan ruko menjadi vihara; 2) Tidak menyalakan dupa dan bunyi-bunyian yang mengganggu lingkungan sekitar.

Berpijak dari realitas tersebut, secara teologis dalam hal peribadatan warga di sekitar lingkungan secara tidak langsung vihara tersebut tidak boleh digunakan untuk tempat ibadah. Padahal dalam keyakinan pemeluk agama Buddha dalam praktik peribadatan membutuhkan sarana prasarana, di antaranya adalah menyalakan dupa. Tata cara dan upacara peribadatan peringatan atau perayaan peristiwa-peristiwa keagamaan Buddha sebagaimana dijelaskan (Manaf, 2006: 40-41) adalah sebagai berikut: kebaktian umum dilaksanakan pada setiap hari Minggu jam 17.00, memanjatkan Paritta kepada Tuhan Yang Maha Esa, Samma Sambuddha dalam bahasa Pali, melaksanakan Samadhi Metta Bhavana diiringi dengan Paritta dalam bahasa Indonesia, pembahasan ayat-ayat suci kitab suci Dharmapada, Upanisada (khotbah) tentang pelajaran agama Buddha dengan diselingi vihara Gita (lagu-lagu rohani), kebaktian pada setiap hari Uposatta (penanggalan bulan Lunar 1 dan 15). Acaranya sama dengan yang tersebut pada ad.1. hanya ada tambahan pemercikan air dan kembang. Selain itu upacara lain adalah, kebaktian pada setiap hari raya suci agama Buddha seperti: hari raya suci Waisak, hari raya suci Asadha, dan hari raya suci Kathina.

Lebih lanjut dijelaskan, bahwa dalam tata cara ritual atau peribadatan sarana prasarana yang dibutuhkan adalah: dupa/hio/kayu garu, bunga/ puspe/puspa, aloke/penerangan/lilin/lampu, argha /air, buah segar, air teh, bhojana/navidya/makanan bergizi, ratna/mustika, mutiara, dan pakaian. Saranan-prasarana tersebut, merupakan bentuk simbol spiritual kepada sang Buddha. Tata cara ritual agama Buddha dalam konteks kekinian, berkenaan dengan kasus alih fungsi ruko menjadi vihara, akan menjadi persoalan tersendiri bagi umat Buddha.

Dalam konteks keyakinan agama Buddha, peniadaan simbol spiritual dapat mengurangi makna dalam keagamaan mereka. Hal ini sebagaimana dijelaskan Newwel (dalam Turner, 2013: 682) bahwa "Buddhisme" secara efektif dipisahkan menjadi dua kutub yang terpisah: 1) Buddhisme yang cukup diidealkan dengan masa silam yang jauh, yang direkonstruksi oleh para pakar dari teksteks dalam bahasa Pali dan Sansekerta, dengan lebih mengutamakan teks-teks yang lebih tua, 2) Umat Buddhis di Asia kotemporer, yang praktik dan preferensinya dipandang bertentangan secara spesifik dengan Buddhisme yang ideal.

\section{Dimensi Sosiologis}

Secara sosiologis, alih fungsi ruko menjadi rumah ibadah (vihara), membawa dampak sosial baik bagi umat Buddha, warga di sekitar vihara, 
maupun bagi pemerintah. Sebagaimana disebutkan dalam hasil rapat FKUB Kabupaten Banyumas tanggal 2 April 2014, bahwa permohonan pemanfaatan ruko menjadi vihara sudah sesuai dengan PBM No. 9 dan 8 tahun 2006. Dengan catatan pengelola vihara menjaga kerukunan, keamanan, perparkiran, dan memperhatikan kondisi bangunan.

Berpijak dari realitas sosial tersebut, Lids dalam Turner (2013: 131) mengemukakan sesungguhnya alih fungsi ruko menjadi vihara telah menjadikan masyarakat melakukan pengkondisian kehidupan agama agar berjalan rukun dan damai. Masyarakat di Kelurahan Sokanegara, khususnya di lingkungan berdirinya vihara secara tidak langsung telah melakukan pembentukan aturan sosial yang harus ditaati oleh pihak vihara. Masyarakat melalui FKUB Kabupaten Banyumas telah membentuk gerakan sosial yang membatasi ruang-ruang kebebasan aktivitas umat Buddha di Kelurahan Sokanegara.

Mengenai hal ini Parsons (dalam Turner, 2013: 133) mengaitkan agama dengan kontrol sosial. Ia sependapat dengan Durkheim bahwa anggota-anggota masyarakat memberlakukan atau memaksakan kepercayaan agama satu sama lain. Sebagai umat minoritas tentu saja umat Buddha dalam hal ini, kurang dapat berdaya mendapat tekanan-tekanan sosial yang dilakukan oleh mayoritas masyarakat.

\section{Penerimaan \\ Aspek administrasi}

Alih fungsi ruko menjadi vihara Prajna Maitreya, pada akhirnya terselesaikan setelah panitia memenuhi persyaratan pendirian rumah ibadah. Hal ini setelah FKUB Kabupaten Banyumas melakukan survey lokasi dan vihara tersebut diberi izin sementara. Berdasarkan data tersebut bangunan vihara hanya mendapat izin sementara dalam pemanfaatannya sebagai rumah ibadah. Di samping itu pula pihak vihara harus menjaga ketertiban, keamanan dan kerukunan bagi masyarakat sekitar.

Mencairnya hubungan antara masyarakat Kelurahan Sokanegara, FKUB Kabupaten Banyumas, dan pihak vihara tidak terlepas dari sikap positif semua pihak. Berkenaan dengan hal ini, Agus Comte (dalam Bungin, 2011: 10) menyebutkan bahwa teori positivisme memiliki pengaruh yang amat kuat terhadap kehidupan sosial masyarakat. Melalui aliran inilah lahir istilah sosiologi. Lebih lanjut dijelaskan bahwa manusia merupakan makhluk sosial yang dalam hidupnya manusia berfungsi bagi yang lain. Oleh karena itu mencairnya potensi konflik alih fungsi ruko menjadi vihara salah satunya adalah karena masyarakat menyadari bahwa pada dasarnya manusia tidak bisa terlepas dari manusia lainnya.

Sementara itu seperti diuraikan Karl Marx, bahwa hubungan manusia satu dengan manusia lainnya tidak terlepas dari komunikasi. Lahirnya sosiologi komunikasi tidak terlepas dari para pemikir filsafat. Para filsuf tersebut diantaranya adalah Auguste Comte, Emile Durkheim, Talcott Parson dan Robert K. Merton yang melahirkan paradigma dalam sosiologi komunikasi aliran filsafat struktural-fungsional. Sementara itu Karl Marx, Jurgen Habermas, dan John Dewey merupakan aliran pemikiran yang melahirkan paradigma dalam sosiologi komuniaksi konflik-kritis (Bungin, 2011: 18-20).

Senada dengan pendapat di atas, Soekanto (dalam Bungin, 2011: 31) menjelaskan bahwa sosiologi komunikasi merupakan kekhususan dalam mempelajari interaksi sosial yaitu suatu hubungan atau komunikasi yang menimbulkan saling mempengaruhi antara para individu, individu dengan kelompok maupun antar kelompok. Dapat pula dikatakan bahwa sosiologi komunikasi berkaitan dengan public speaking, yaitu bagaimana kemampuan seseorang berbicara kepada publik. Komunikasi dalam masyarakat dibagi dalam 5 jenis yaitu: 1) komunikasi individu dengan individu (komunikasi antar personal), 2) komunikasi kelompok, 3) komunikasi organisasi, 4) komunikasi sosial, dan 5) komunikasi massa.

Berpijak dari ranah sosiologi komunikasi tersebut, komunikasi yang dibangun oleh masyarakat Kelurahan Sokanegara, FKUB kabupaten Banyumas, dan pihak vihara Prajna Maitreya adalah selaras dengan teori komunikasi. Potensi konflik berkaitan dengan keberadaan vihara Prajna Maitreya, oleh kelompok masyarakat, FKUB dan pihak vihara telah terjalin komunikasi dialogis. Sehingga potensi yang muncul dapat diantisipasi dengan jalan dialog yang dilakukan secara intensif dan terus menerus. Kelima ranah sosiologi komunikasi tersebut membentuk suatu lingkaran budaya di masyarakat, sehingga antara individu, kelompok masyarakat, media, budaya, teknologi, dan proses interaksi 
sosial berjalan dengan baik dan membentuk suatu hubungan yang rukun baik antara invidu maupun dengan kelompok.

\section{Aspek Teologi}

Pendirian vihara Prajna Maiteya secara teologis bagi masyarakat sekitar dapat menerima keberadaan vihara. Namun demikian, penerimaan tersebut melalui persyaratan yang harus dilaksanakan oleh pihak vihara. Syarat utama yang harus dipenuhi adalah bahwa masyarakat dapat menerima keberadaan vihara apabila pengelola vihara tidak merubah bentuk ruko menjadi bentuk vihara, tidak menyalakan dupa dan membunyikan bunyi-bunyian dalam melakukan peribadatan. Selain itu, agar pihak pengelola vihara menjaga kerukunan baik antar umat beragama maupun intern beragama.

Berbeda dengan penerimaan ruko menjadi vihara, penerimaan pendirian masjid Baiturrahman oleh masyarakat warga RT. 01 RW. 05 Kelurahan Sokanegara, masyarakat sekitar terutama masyarakat non muslim dapat menerima pendirian masjid dengan catatan, pengeras suara tidak diarahkan ke arah utara, di tempat tersebut merupakan tempat para biarawati.

Berkenaan dengan penerimaan alih fungsi ruko menjadi rumah ibadah umat Buddha (vihara) dan pendirian masjid Baiturrahman ini tidakterlepas dari peran FKUB Kabupaten Banyumas. Peran FKUB Kabupaten Banyumas dalam penyelesaian pendirian rumah ibadah adalah membangun budaya dialog dengan berbagai pihak. Pihak-pihak yang dilibatkan dalam penyelesaian pendirian rumah ibadah di antaranya masyarakat setempat berdirinya rumah ibadah, tokoh masyarakat, tokoh agama, Pemerintah Kabupaten Banyumas, dan Kementerian Agama Kabupaten Banyumas.

Dengan pendekatan budaya dialog inilah, potensi konflik yang muncul dapat diselesaikan. Budaya menurut Tylor (dalam Liliweri, 2007: 107-110) adalah kompleksitas dari keseluruhan pengetahuan, kepercayaan, kesenian, hukum, adat istiadat dan setiap kemampuan lain dan kebiasaan yang dimiliki oleh manusia sebagai anggota suatu masyarakat. Lebih lanjut dijelaskan bahwa budaya dalam pandangan sosiologi budaya adalah: 1) keseluruhan (total) atau pengorganisasian way of life termasuk nilai-nilai, norma-norma, institusi, dan artifak yang dilaihkan dari satu generasi kepada generasi berikutnya melalui proses belajar; 2) pola-pola perilaku yang dihasilkan oleh interaksi sosial atau semua perilaku dan semua produk yang dihasilkan oleh seseorang sebagai anggota suatu masyarakat yang ditemukan melalui interaksi simbolik; 3) sesuatu yang terbentuk oleh pengembangan dan transmisi dari kepercayaan manusia melalui simbol-simbol tertentu.

Rekacipta budaya yang dilakukan oleh FKUB Kabupaten Banyumas dengan komponen masyarakat dan pemerintah telah membentuk budaya damai, sehingga kasus-kasus keagamaan terutama pendirian rumah ibadah di Kabupaten Banyumas dapat diselesaikan tanpa insiden yang berarti. Hal ini dapat diketahui dari penyelesaian kasus masjid Al-Fattah Sumampir, pendirian Pure SPN, pendirian gereja Saksi-Saksi Yehuwa Indonesia Purwokerto, penanganan kasus Ahmadiyah di Purwokerto, pendampingan alih ruko menjadi vihara, melakukan kajian ayat-ayat perdamaian, siaran radio Islam inklusif bekerjasama dengan Radio Dian Suara dan lain-lain. Kasuskasus keagamaan tersebut sebagian besar dapat diselesaikan dengan pendekatan budaya.

\section{Aspek Sosiologis}

Mencairnya hubungan masyarakat di Kabupaten Banyumas tidak terlepas dengan kondisi sosial budaya masyarakat Banyumas itu sendiri. Keunikan budaya Banyumas yang dibangun dengan konsep budaya "cablaka" membawa dampak yang baik dalam menyelesaikan suatu persoalan. Salah satunya adalah dalam menyelesaikan persoalan pendirian rumah ibadah. Budaya cablaka adalah menyampaikan sesuatu tanpa tedeng aling-aling yang berarti menyampaikan dengan apa adanya.

Sehubungan dengan budaya cablaka tersebut, masyarakat Banyumas dalam berinteraksi atau berkomunikasi cenderung mudah menerima perbedaan dan tidak mudah tersulut dalam konflik horisontal. Selain itu pula, budaya cablaka ikut berperan dalam membangun jaringan komunikasi dalam masyarakat Banyumas.

Berdasarkan kerangka sosiologi komunikasi tersebut, dapat dijelaskan bahwa hubungan antar individu, tokoh masyarakat, tokoh agama, tokoh budaya, Pemerintah Daerah, FKUB, dan Kementrian Agama di Banyumas terjalin dengan baik. Potensi-potensi konflik yang muncul baik dalam kehidupan beragama dan masyarakat secara umum bisa diantisipasi dengan komunikasi budaya. 


\section{PENUTUP}

Berdasarkan uraian-uraian di atas mengenai pendirian rumah ibadah di Purwokerto khususnya alih fungsi ruko menjadi vihara Prajna Maitreya dan pendirian masjid Baiturrahman dapat disimpulkan sebagai berikut:

Bahwa regulasi PBM No 9 dan 8 tahun 2009 terutama tentang pendirian rumah ibadah di Purwokerto sebagaimana tercantum dalam pasal $13,14,15,16,17$, dan 18 , sebagian kecil sudah sesuai dengan peraturan tersebut. Hal ini sebagaimana telah diterapkan dalam pendirian vihara Prajna Maitreya. Sementara itu untuk pendirian masjid di Kabupaten Banyumas secara umum bahwa 90\% belum berizin. Pendirian masjid yang sedang dalam proses pembangunan dan menyesuaikan PBM tersebut adalah masjid Baiturrahman di Kelurahan Sokanegara, Kecamatan Purwokerto Timur, Kabupaten Banyumas.

Pendirian vihara Prajna Maitreya sebelumnya tidak diterima masyarakat dan berpotensi menimbulkan konflik. Setelah pihak panitia memenuhi peraturan yang berlaku, masyarakat dapat menerima keberadaan vihara tersebut. Secara teologis masyarakat menerima keberadaan vihara tersebut dengan catatan tidak merubah bentuk ruko menjadi vihara, tidak menyalakan dupa, dan membunyikan peralatan ibadah, serta menjaga ketertiban, kerukunan di masyarakat.

Penerimaan alih fungsi ruko menjadi vihara selain syarat administrasi terpenuhi, juga karena adanya aspek lain. Aspek tersebut adalah keterbukaan masyarakat dalam hal sosial budaya. Budaya masyarakat Banyumas yang memiliki karakter dengan istilah cablaka, ikut mewarnai budaya damai di masyarakat.

\section{UCAPAN TERIMA KASIH}

Pada kesempatan ini penulis menyampaikan terima kasih kepada FKUB dan Kementerian Agama Kabupaten Banyumas yang telah memberikan data terkait pendirian rumah ibadah. Selain itu pula secara khusus penulis menyampaikan terima kasih kepada KH Dr. Moh Roqib, M.Ag yang telah berkenan meluangkan waktunya untuk berdisukusi seputar masalah pendirian rumah ibadah di Kabupaten Banyumas.

\section{DAFTAR PUSTAKA}

Ahmad, Haidar Ali. 2012. Hubungan Umat Beragama: Studi Kasus Penutupan/ Perselisihan Rumah Ibadah. Jakarta: Kemenetrian Agama RI Badan Litbang dan Diklat Puslitbang Kehidupan Keagamaan.

Asry, Muhammad Yusuf. 2011. Pendirian Rumah Ibadah di Indonesia: Pelaksanaan Peraturan Bersama Menteri Agama dan Menteri Dalam Negeri Nomor 9 dan 8 Tahun 2006. Jakarta: Kementerian Agama RI Badan Litbang dan Diklat Puslitbang Kehidupan Keagamaan.

Badan Litbang dan Diklat Departemen Agama RI. 2008. Sosialisasi PBM dan Tanya Jawabnya. Jakarta: Kementerian Agama RI.

Bagir, Zainal Abidin dkk. 2011. Laporan Tahunan Kehidupan Beragama di Indonesia. Yogyakarta: Program Studi Agama dan Lintas Budaya (Center For Religious and Crosscultural Studies).

Bungin, M Burhan. 2011. Sosiologi Komunikasi Teori, Paradigma, dan Diskurus Teknologi Komunikasi di Masyarakat. Jakarta: Kencana Prenada Media Group.

Haryanto, Joko Tri. 2014. Kearifan Lokal Pendukung Kerukunan Beragama pada Komunitas Tengger, Malang, Jawa Timur, Jurnal Analisa Balai Litbang Agama Semarang Volume 21 No. 2 Desember 2014

Khalikin, Ahsanul. 2010. Pendirian Rumah Ibadah dalam Perspektif PBM No. 9 dan 8 Tahun 2006: Kasus Pencabutan IMB Gereja HKBP Pangkalan Jati Gandul, Kec Limo Kota Depok. Jurnal Harmoni Volume IX, Nomor 35: 190.

Koentjaraningrat. 1985. Javanese Culture. Singapure: Oxford University Press.

Kustini. 2010. Peranan Forum Kerukunan Umat Beragama dalam Pelaksanaan Pasal 8, 9, dan 10 Peraturan Bersama Menteri Agama dan Menteri Dalam Negeri Nomor 9 dan 8 Tahun 2006. Jakarta: Kemenetrian Agama RI Badan Litbang dan Diklat Puslitbang Kehidupan Keagamaan.

Manaf, Muhammad Abdul. 2006. Sejarah AgamaAgama. Surakarta: UNS Press.

Muchtar, Ibnu Hasan. 2010. Dilema Pendirian Rumah Ibadah: Studi Pelaksanaan PBM No. 9 dan 8 Tahun 2006 di Kota Bekasi. Jurnal Harmoni Volume IX, Nomor 35: 98. 
Roqib, Moh. 2012. Membumikan Pluralisme dan Kerukunan Umat Beragama: Guyub Rukun Bersama FKUB Banyumas. Banyumas: FKUB Banyumas dan Pesma An Najah Press.

Suwito NS. 2008. Islam dalam Tradisi Begalan. Yogyakarta: Grafindo Litera Media.
Praja, Juhaya S. 2010. Aliran-Aliran Filsafat dan Etika. Jakarta: Kencana Prenada Media Group.

Priyadi, Sugeng. "Orientasi Nilai Budaya Banyumas: antara Masyarakat Tradisional dan Modern". Jurnal Humaniora Volume 20 No. 2 Juni 2008. 